amyloid stroma is demonstrated by specific staining techniques (Gérard-Marchant, 1965). We have not observed it in two cases of papillary cancer.

The question is now raised whether this activity is due to the presence of thyrocalcitonin or to another substance with a similar biological activity. Two arguments favour thyrocalcitonin hypothesis: the purification procedure used is that which serves to demonstrate the presence of thyrocalcitonin in normal human thyroid gland, and which currently is used to prepare pork thyrocalcitonin. Further, the ratios of hypocalcaemic and hypophosphataemic activity are very close to those for thyrocalcitonin. Our results, in particular the presence of thyrocalcitonin in involved nodes, suggest that medullary cancer with amyloid stroma is a secreting tumour whose cells are developmentally different from those that stem from the follicular cells. The fact that these tumours contain no iodine (Ljungberg, 1966) supports that hypothesis.

Williams (1966) has supposed that these cancers develop from the parafollicular cells and may produce thyrocalcitonin, but has not presented experimental evidence to support this. Our observations therefore are the first to show evidence of the part played in human pathology by these thyrocalcitoninproducing cells.

We have not observed hypocalcaemia in these cases in spite of the presence of thyrocalcitonin. Moreover, hypercalcaemia was present in three patients. These paradoxical findings have no good explanation at the present time, but suggest overreaction of a compensatory mechanism.

What is the role of amyloid substance in medullary cancer of the thyroid? We have not found thyrocalcitonin activity in our one case without amyloid stroma. It would be interesting to determine if the medullary cancers without amyloid stroma described by Williams (1966) in dogs and rats have any thyrocalcitonin activity. On the other hand, if it is confirmed in man that the medullary cancer without amyloid stroma has no thyrocalcitonin activity, it might be possible by biological assay to distinguish the two types of cancer.

Finally the diarrhoea cannot be explained by the hyperproduction of thyrocalcitonin, as no diarrhoea was observed in two patients (Cases 2 and 4) in whom tumour contained a high amount of thyrocalcitonin. Furthermore, animals injected with very high doses of thyrocalcitonin (1,000 milliunits) presented no diarrhoea (Milhaud, personal communication). One can reconcile this with the fact that Williams et al. (1968) demonstrated the presence of prostaglandin substance having a motor action on smooth muscle in several patients. It would be interesting to study this problem in order to determine if there is a correlation between prostaglandin and thyrocalcitonin concentration, or if they are independent.

We would like to express our thanks to Dr. Gérard-Marchant, Chief of the Pathology Department, and to Dr. J. Roujeau for their co-operation and their interest in this study.

\section{REFERENCES}

Aliapoulios, M. A., Voelkel, E. F., and Munson, P. L. (1966). 7. clin. Endocr., 26, 897.

Baghdiantz, A., et al. (1964). Nature (Lond.), 203, 1027.

Gerard-Marchant, R. (1965). F. Chir. (Paris), $90,337$.

Hazard, B., Hawk, W. A. and Crile, G., jun. (1959). \%. clin. Endocr. 19, 152 .

Kumar, M. A., et al. (1965). \%. Endocr., 33, 469

Ljungberg, O. (1966). Acta path. microbiol scand., 68, 476.

Meyer, J.'S., and Abdel-Bari, W. (1968). New Engl. Ұ. Med., 278, 523. Milhaud, G., Tubiana, M., Parmentier, C., and Coutris, G. (1968). C.R Acad. Sci. (Paris), Series D, 266, 608 .

Tashjian, A. H., Frantz, A. G., and Lee, J. B. (1966). Proc. nat. Acad. Sci. (Wash.), 56, 1138.

Williams, E. D. (1966). F. clin. Path., 19, 114.

Williams, E. D., Brown, C. L., and Doniach, I. (1966). F. clin. Path.

Williams, E. D., Karim, S. M. M., and Sandler, M. (1968). Lancet, 1, 22 .

\title{
Rapid Diagnosis of Herpesvirus hominis Infections in Superficial Lesions by Immunofluorescent Antibody Techniques
}

\author{
P. S. GARDNER,* M.D., DIP.BACT. ; JOYCE MCQUILLIN,* B.SC., F.I.M.L.T. ; M. M. BLACK, $\dagger$ M.B., M.R.C.P. \\ J. RICHARDSON, $\ddagger$ M.B., F.R.C.S.
}

[With Special Plate between Pages 94 and 95]

Brit. med. F., 1968, 4, 89-92

\begin{abstract}
Summary : Scrapings from lesions of the skin and $\checkmark$ mucous membranes of 14 patients suspected of suffering from suspected Herpesvirus hominis infections were examined by both fluorescent antibody and routine isolation techniques. There was complete correlation between results by both methods in all 14 cases, 12 being positive. No positive fluorescence was obtained from scrapings of seven control patients with a variety of skin diseases. Thirteen patients with corneal lesions were similarly investigated. Of the 10 scrapings which showed positive fluorescence, nine were confirmed by virus isolation. It is suggested that as more antiviral agents become available the application of a fluorescent antibody technique for testing virus sensitivity in tissue culture could become a practical method.
\end{abstract}

* Department of Virology.

t Department of Dermatology.

t Department of Ophthalmology.

University of Newcastle upon Tyne and Roval Victoria Infirmary, Newcastle upon Tyne 1.
con

\section{Introduction}

Herpesviress hominis is a ubiquitous virus causing a variety of illnesses, and two of the most common conditions with which it is associated are corneal infections and lesions of the skin and mucous membranes. In recent years claims have been made that the virus is sensitive to the antiviral agent 5-iodo-2'deoxyuridine (idoxuridine) (Kaufman, 1962; Kaufman, Martola, and Dohlman, 1962).

It is therefore surprising that greater attempts have not been made to establish methods of rapid diagnosis for this virus, especially as material is readily accessible from the superficial lesions. Biegeleisen, Scott, and Lewis as long ago as 1959 correlated virus isolation with the fluorescent staining of skin lesions, but no further attempts were made to exploit this method. Kaufman (1960) and Pettit, Kimura, and Peters (1964) stained cell scrapings both from rabbits whose corneas had been experimentally infected with Herpesvirus hominis and from human cases of ocular herpetic infections and found a close correlation between their isolation and fluorescent anti- 
body techniques. Though this work appeared to be successful for the rapid diagnosis of Herpesvirus hominis infections of the cornea, there has been no general use of the method since that date, and in most virus laboratories conventional isolation and serological techniques are still the methods of choice for the diagnosis of infection by this virus. Now that an antiviral agent is available for the treatment of infection with Herpesvirus hominis, every effort should be made to diagnose the infection rapidly and accurately. This communication reports the result of a comparison of isolation and fluorescent antibody techniques on a series of corneal lesions and vesicular lesions of the skin.

\section{Materials and Methods}

The techniques and methods used were those reported recently from this laboratory (Gardner and McQuillin, 1968 ; McQuillin and Gardner, 1968) and only differences in procedures will be noted here.

Corneal Scrapings.-Corneal lesions of 13 patients were scraped with a scalpel so that the epithelium was removed. The tissue fragments were placed in two spots of the phosphate buffered saline on a slide and large fragments were broken up, as far as possible, by teasing with needles. The spots were then allowed to dry in air and immediately fixed for 10 minutes in acetone at $4^{\circ} \mathrm{C}$. The scalpel blade was thoroughly rinsed in Hanks's medium containing 0.2 bovine albumin, and these washings were used for the culture of the virus; a swab was also taken from the area, broken into the same media; specimens were transported to the laboratory on ice and used for virus culture.

Skin Scrapings.-Fourteen patients with possible herpetic lesions of the skin were investigated (see Table I). Some were classical herpesvirus lesions, but many, though suspected of having this aetiology, required laboratory confirmation. Specimens were taken from vesicular lesions for preference. Crusted areas were not satisfactory. The vesicles were opened and a swab of the vesicle fluid was broken into transport medium for subsequent virus culture. The base of the lesion was then scraped with a scalpel and the material treated as previously described for the corneal scrapings, including a specimen for subsequent virus culture.

Antiherpetic Rabbit Serum.-This was prepared by inoculating rabbits with an egg-cultured virus. The serum was kindly prepared and supplied to us by Winthrop Biologicals Limited.

Fluorescein-conjugated Anti-rabbit Globulin.-This reagent, Fluoroscan Plus, has been fully described in our previous communications and was again supplied to us by Winthrop Biologicals Limited.

Virus Isolation Techniques and Neutralization Tests.-The cell lines used for culture were HEp.2, HeLa, and W.I.38. Virus isolates were grown in duplicate tissue culture tubes, one of which was used to confirm the identity of the virus by routine neutralization test, based on the method previously described (Andrew and Gardner, 1963). Cells from the second tube were scraped off and examined by fluorescent antibody technique, the slides being prepared by the same method as previously described for the examination of tissue culture cells infected with respiratory syncytial virus (McQuillin and Gardner, 1968).

Preparation of Slides for Staining and Examination.-Slides from tissue culture material contained three spots, the first being infected cells to be treated with herpesvirus antiserum, the second being infected cells to be treated with normal rabbit serum, and the third was uninfected cells of the same batch to be treated with herpesvirus antiserum. All these spots were then stained with Fluoroscan Plus. Slides of corneal and skin scrapings contained two spots only, one to be treated with herpesvirus antiserum and the other with normal rabbit serum; both were then stained with Fluoroscan Plus.
Fluorescent Microscopy.-Specimens were examined under dark-ground illumination by blue light by means of a Wild M20 fluorescent microscope with an Osram HBO 200 mercury vapour lamp, a blue BG $12 / 4 \mathrm{~mm}$. exciter filter, and an OG1 barrier filter. Photographs were taken on the same microscope. All exposures were of 180 seconds' duration, an Ilford Mark V film being used.

\section{Results}

\section{Specificity of Herpesvirus Antiserum}

(a) A variety of uninfected human tissue culture cells and also monkey kidney tissue culture cells were tested with herpesvirus antiserum on innumerable occasions and showed no evidence of non-specific staining.

(b) The following viruses growing on tissue culture were treated with herpesvirus antiserum and subsequently stained with Fluoroscan Plus: influenza A, parainfluenza virus type 3, polioviruses types 1,2 , and 3 , adenoviruses 1,2 , and 5 , echoviruses 9,12 , and 30 , coxsackieviruses types B3 and B5, and an $M$ type rhinovirus. None showed any non-specific fluorescence with this antiserum and Fluoroscan Plus.

\section{Confirmation of Cytopathic Effects}

During the course of this investigation 23 isolations of Herpesvirus hominis were made on tissue culture and confirmed by neutralization test. In each case cells from the partner tissue culture tube tested by the fluorescent antibody technique proved positive.

Fig. 1 (Special Plate) shows positive staining by the fluorescent antibody technique in a degenerating HEp.2 culture infected with Herpesvirus hominis. The cells show a generalized particulate fluorescence. In many there is some concentration of fluorescence at the periphery. Even at a later stage of degeneration the intranuclear inclusion bodies are not in evidence by this method.

\section{Skin and Corneal Scrapings}

Figs. 2 and 3 (Special Plate) show typical corneal epithelial cells in scrapings stained by fluorescent antibody technique from two patients with "dendritic ulcers." Fig. 2 shows two cells exhibiting generalized particulate fluorescence adjacent to a few unstained normal epithelial cells. Fig. 3 shows a single cell with intense particulate fluorescence of the whole cell.

Figs. 4 and 5 (Special Plate) show cells from skin scrapings of patients with suspected herpetic lesions and stained by the fluorescent antibody technique. These infected cells show the characteristic particulate fluorescence, which has a greater tendency to be concentrated at the cell periphery. Controls of these materials were treated with normal rabbit serum and Fluoroscan Plus, and were always negative.

Table I shows the clinical diagnosis and the comparison between direct examination of the lesions by the fluorescent antibody technique and by conventional isolation methods. Cases 1-14 are patients with lesions of skin and mucous membranes.

Cases 1-6 suffered from classical recurrent herpetic infections on the face and lips (cold sores). Recurrences were frequent in the patients studied and the vesicles invariably occurred at an identical site.

Cases 7-11 were strongly suspected of having primary herpetic infections. In the majority the illness began with fever, malaise, and stomatitis, later tender enlarged cervical lymph nodes were noted. In all patients the mucous membrane lesions were small and haemorrhagic, and were found on the tongue, pharynx, palate, and buccal areas. No intact vesicles were seen in any patients, and, because of this, aphthosis, herpangina, and Stevens-Johnson syndrome had to be considered. 
TABLB I.-Comparison of Fluorescent Antibody and Isolation Techniques of Skin and Corneal Lesions

\begin{tabular}{|c|c|c|c|c|c|}
\hline $\begin{array}{l}\text { Case } \\
\text { No. }\end{array}$ & $\begin{array}{c}\text { Age } \\
\text { in } \\
\text { Years }\end{array}$ & \multicolumn{2}{|r|}{ Clinical Data } & $\begin{array}{c}\text { Direct } \\
\text { Fluorescent } \\
\text { Antibody } \\
\text { Results for } \\
\text { Herpesvirus }\end{array}$ & $\begin{array}{c}\text { Tissue } \\
\text { Culture } \\
\text { Isolation } \\
\text { for } \\
\text { Herpesvirus }\end{array}$ \\
\hline 1 & 28 & \multicolumn{2}{|c|}{$\begin{array}{l}\text { Recurrent herpetic vesicles on right } \\
\text { cheek }\end{array}$} & Poritive & Ponitive \\
\hline 2 & 20 & \multirow{2}{*}{\multicolumn{2}{|c|}{$\begin{array}{l}\text { Recurrent herpetic vesicles on left } \\
\text { cheek }\end{array}$}} & Fositive & gostave \\
\hline 3 & 18 & & & $"$ & $"$ \\
\hline 4 & 33 & \multicolumn{2}{|c|}{$\begin{array}{l}\text { Recurrent herpetic vesicles on lower } \\
\text { lip } \ddot{0} \text {. } \\
\text { Recurrent herpetic vesicles on upper }\end{array}$} & $"$ & " \\
\hline 5 & 39 & \multicolumn{2}{|c|}{$\begin{array}{l}\text { lip } \\
\text { Recurrent herpetic vesicles on left }\end{array}$} & $\because$ & \\
\hline 6 & 21 & \multicolumn{2}{|c|}{$\begin{array}{l}\text { cheek } \\
\text { Recurrent herpetic vesicles on left }\end{array}$} & $"$ & , \\
\hline 7 & 18 & \multicolumn{2}{|c|}{ Stomatititis. $\ddot{\text { Vesicopustular } \ddot{~ l e s i o n s ~}}$} & , & , \\
\hline 8 & $6 / 12$ & \multirow{2}{*}{\multicolumn{2}{|c|}{$\begin{array}{l}\text { Acute spreading vesicular eruption on } \\
\text { face and anterior chest wall }\end{array}$}} & r. & $"$ \\
\hline 9 & 3 & & & $"$ & $"$ \\
\hline 10 & 2 & \multicolumn{2}{|c|}{$\begin{array}{l}\text { Febrile illness with acute stomatitis. } \\
\text { No skin lesions } \\
\text { Acute spreading vesicular erüption ö }\end{array}$} & $"$ & ", \\
\hline 11 & $6 / 12$ & \multicolumn{2}{|c|}{ 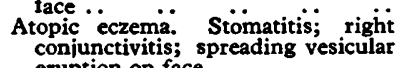 } & $"$ & $"$ \\
\hline 12 & 36 & \multicolumn{2}{|c|}{$\begin{array}{l}\text { eruption on face } \\
\text { Ulcerating lesions on lower lips and } \\
\text { nostrils }\end{array}$} & $"$ & $"$ \\
\hline $\begin{array}{l}13 \\
14\end{array}$ & $\begin{array}{l}21 \\
31\end{array}$ & \multicolumn{2}{|c|}{$\begin{array}{l}\text { nostrtils } \\
\text { Acute pustular eruption on left cheeek } \\
\text { Recurrent pustular eruptions on both }\end{array}$} & $\begin{array}{c}\text { Negative } \\
\quad \#\end{array}$ & $\begin{array}{c}\text { Negative } \\
\quad \#\end{array}$ \\
\hline \multirow{7}{*}{$\begin{array}{l}15 \\
16 \\
17 \\
18 \\
19 \\
20 \\
21 \\
22 \\
23 \\
24 \\
25 \\
26 \\
27\end{array}$} & \multirow{7}{*}{$\begin{array}{l}59 \\
69 \\
60 \\
43 \\
50 \\
59 \\
50 \\
55 \\
30 \\
71 \\
65 \\
46 \\
24\end{array}$} & & Positive & Positive \\
\hline & & \multicolumn{2}{|c|}{$\begin{array}{l}\text { Recürrent coorneal ulceration } \\
\text { Dendritic ulcer }\end{array}$} & Negative & Negative \\
\hline & & " & $\because$ & Posỉive & Positive \\
\hline & & $"$ & $\because$ & $\begin{array}{l}\text { Negative } \\
\text { Positive }\end{array}$ & $\begin{array}{l}\text { Negative } \\
\text { Positive }\end{array}$ \\
\hline & & $"$ & $\because$ & $"$ & $"$ \\
\hline & & $"$ & .. & " & $"$ \\
\hline & & $"$ & $\because$ & $"$ & $"$ \\
\hline
\end{tabular}

Case 11-a 6-month-old-child with atopic eczema-in addition to having stomatitis, developed a spreading vesicular eruption on the face with conjunctivitis of the right eye. The child had not been recently vaccinated, so a diagnosis of eczema herpeticum was suggested and rapidly confirmed by the fluorescent antibody technique.

Case 12, a 36-year-old woman, presented with a three-week history of spreading ulcerating lesions on the lower lip and in the vicinity of the nostrils. She had recently had a renal transplant and was receiving a combination of oral immunosuppressive drugs and corticosteroids. The lesions were not classically herpetic, but she gave a history of having had cold sores at the same sites.

Cases 13 and 14 presented with acute pustular eruptions on the face. Though the lesions were not typical of herpes simplex both patients claimed to have had cold sores at a similar site in the past.

Cases 15-27 were patients with corneal lesions. These had the typical clinical appearances of "dendritic ulcers" except in Case 17, in which the lesion was a recurrent corneal ulceration.

Table II shows a number of control cases; the patients with chicken-pox and herpes zoster are of particular significance, since they confirm the specificity of the test even with viruses of the same group.

TABLE II.- Examinations of Skin Lesions of Control Patients by Fluorescent Antibody and Isolation Techniques

\begin{tabular}{|c|c|c|c|c|c|c|}
\hline $\begin{array}{l}\text { Case } \\
\text { No. }\end{array}$ & Age & Clinical Diagn & & & $\begin{array}{l}\text { Direct } \\
\text { Fluorescent } \\
\text { Antibody } \\
\text { Results for }\end{array}$ & $\begin{array}{c}\text { Tissue } \\
\text { Culture } \\
\text { Isolation }\end{array}$ \\
\hline $\begin{array}{l}28 \\
29 \\
30 \\
31 \\
32 \\
33 \\
34\end{array}$ & $\begin{array}{r}37 \\
6 \\
66 \\
68 \\
81 \\
52 \\
5\end{array}$ & $\begin{array}{l}\text { Herpes zoster } \\
\text { Chicken-pox .. } \\
\text { Discoid eczerma of legs } \\
\text { Seborrhoeic dermatitis } \\
\text { Bullous pemphigoid } \\
\text { Herpes zoster } \\
\text { Chicken-pox .. } \quad . .\end{array}$ & $\begin{array}{l}\because \\
\because \\
\because \\
\because\end{array}$ & $\begin{array}{l}\ddot{0} \\
\ddot{0} \\
\ddot{.}\end{array}$ & $\begin{array}{l}\text { Negative } \\
\text { "” } \\
\text { ”" } \\
\text { ", }\end{array}$ & $\begin{array}{l}\text { Negative } \\
\text { ", } \\
\text { " } \\
\text { " }\end{array}$ \\
\hline
\end{tabular}

Skin lesions yield abundant material for virus isolation, and the average time for the appearance of a typical herpesvirus cytopathic effect was 4.3 days. On the other hand, the limited material available from corneal scrapings for culture was re- flected in the comparatively long interval before the appearance of cytopathic effect, which averaged 14.5 days.

\section{Discussion}

A reliable test is described for the rapid diagnosis of Herpesvirus hominis infection of skin and corneal lesions.

Positive fluorescent antibody staining of direct material from skin lesions of 12 patients was confirmed by subsequent virus isolation. The two scrapings with negative fluorescent antibody staining also failed to yield Herpesvirus hominis by isolation techniques.

Ten of the corneal scrapings when stained by this technique were positive, though only nine subsequently yielded virus. This one failure could well be due to the minute amount of material available for tissue culture inoculation after smears had been prepared. This is substantiated by the relative difference in the time of recognition of typical cytopathic effect of herpesvirus in material inoculated from skin and corneal scrapings. It would appear that diagnosis of corneal infections by means of the fluorescent antibody technique might be as sensitive as the conventional isolation methods, if not more sensitive. The success and accuracy of the diagnosis of herpesvirus infection in scrapings from both cornea and skin depend on the presence on the slides of adequate numbers of intact cells, and the fluorescence must be intracellular.

In order to evaluate the efficacy of the fluorescent antibody technique it was essential to have optimal conditions for the isolation of the virus. This was achieved by using three separate tissue culture cell lines and also by ensuring that material for inoculation arrived in the laboratory in transport medium and on ice within minutes of leaving the patient. Specimens, so far as was possible, were inoculated on to tissue cultures immediately after arrival.

The use of the fluorescent antibody technique for the confirmation of isolations appears to be as sensitive and reliable as the neutralization test.

The methods described are based on those for the rapid diagnosis of respiratory syncytial virus infection (Gardner and McQuillin, 1968 ; McQuillin and Gardner, 1968) and the same advantages apply to the diagnosis of Herpesvirus hominis. Tedious tissue culture methods can be avoided, both for the isolation of virus and for the neutralization of suspected agents. A confident diagnosis can be made in three hours, and by this type of investigation many more corneal lesions can be examined, with a greater insight into their virus aetiology. Our limited series would suggest that some "dendritic ulcers" are not of herpetic origin. Herpetic lesions of skin and eye are being treated with idoxuridine, and for effective control of this drug, and knowledge of its success, examination of direct material from lesions forms a rapid and accurate measure.

Recently there have been two reports of patients with a herpes simplex encephalitis treated with idoxuridine (Buckley and MacCallum, 1967 ; Evans et al., 1967). Both patients had brain biopsy material taken, and these would appear to be examples of the scope of this procedure in diagnostic work. The urgency to begin chemotherapy in these conditions is paramount, and it seems to us that our methods could be adapted for the rapid diagnosis of encephalitis caused by Herpesvirus hominis.

As more antiviral agents become available, the application of a fluorescent antibody technique for testing virus sensitivity in tissue culture could become a practical method (Oxford and Schild, 1968).

This publication is in the nature of a preliminary communication to present evidence that a method for the rapid diagnosis of Herpesvirus hominis infections is available. The precise relation of clinical cases to virus diagnosis will be published in detail at a later stage. 
We wish to thank Professor Sam Shuster, Mr, N. Manson, and Mr. A. L. Crombie for their help in the investigation of patients under their care and Mr. R. Laidler and Miss R. Huddart for technical assistance. We also wish to thank Winthrop Biologicals Limited for their reagents.

\section{REPERENCES}

Andrew, J. D., and Gardner, P. S. (1963). Brit. med. F., 2, 1447. Biegeleisen, J.' Z., jun., Scott, L. V., and Lewis, V., jun. (1959). Science, 129,640 .
Buckley, T. F., and MacCallum, F. O. (1967). Brit. med. F., 2, 419.

Evans, A. D., Gray, O. P., Miller, M. H., Verrier Jones, E. R., Weeks, R. D., and Wells, C. E. C. (1967). Brit. med. ఫ., 2, 407

Gardner, P. S., and McQuillin, J. (1968). Brit. med. F., 3, 340

Kaufman, H. E. (1960). Arch. Ophthal., 64, 382

Kaufman, H. E. (1962). Proc. Soc. exp. Biol. (N.Y.), 109, 251.

Kaufman, H. E., Martola, E.-L., and Dohlman, C. (1962). Arch. Ophihal., 68, 235 .

McQuillin, J., and Gardner, P. S. (1968). Brit. med. 7., 1, 602.

Oxford, J. S., and Schild, G. C. (1968). F. gen. Virol., 2, 377.

Pettit, T. H., Kimura, S. J., and Peters, H. (1964). Arch. Ophthal., 72,

\title{
Haemoglobin Stanleyville II ( $\alpha 78$ Asparagine $\rightarrow$ Lysine)
}

\author{
G. VAN ROS,* M.D.; D. BEALE, † B.SC. ; H. LEHMANN,† M.D., SC.D., F.R.C.P.
}

[With Special. Plate facing Page 95]

Brit. med. F., 1968, 4, 92-93

\begin{abstract}
Summary : A fourth observation of haemoglobin Stanleyville II has been made. The affected person was a 17-year-old female from the north-eastern area of the Congo Republic, which is entirely inhabited by Nilotes. The amino-acid substitution was found to be a replacement of the asparagine residue by one of lysine in the 78th position of the 141 of the $\alpha$-chain.
\end{abstract}

\section{Introduction}

Haemoglobin Stanleyville II was first described in two families from the area where the north-east of the Congo Republic borders on the Sudan (Dherte, Vandepitte, Ager, and Lehmann, 1959). One family belonged to the Budu tribe, which was considered Bantu but which is surrounded by Nilotic tribes; the other family came from the region of the river Uele, where the population is of mixed Bantu-Nilotic stock. The mother of the propositus, from whom the haemoglobin had been inherited, was of mixed Greek-African origin. On electrophoresis at alkaline $\mathrm{pH}$ on paper and on starch $\mathrm{Hb}$ Stanleyville II has the mobility of Haemoglobin S or D ; on electrophoresis at $\mathrm{pH} 6$ it also resembles $\mathrm{Hb} \mathrm{D}$ Punjab by not separating from Haemoglobin A. On column chromatography on amberlite resin at $\mathrm{pH} 6 \mathrm{Hb}$ Stanleyville moves, however, behind $\mathrm{Hb} S$ and $\mathrm{D}$.

A third family with this haemoglobin was described by HallCraggs, Marsden, Raper, Lehmann, and Beale (1964). It was of Nilotic origin and belonged to the Ulur tribe, which lives in the Western Nile region of Uganda. Little material was available, and the condition of the specimens was not very good. However, it was possible to demonstrate that Stanleyville II was an $\alpha$-chain mutant, and the family study showed independent segregation of $\mathrm{Hbs} \mathrm{A}, \mathrm{S}$, and Stanleyville II. It was suggested that the mutation was in the region of residues 93-139 of the $\alpha$-chain. It has now been possible to place the amino-acid substitution within the tryptic peptide comprising residues $62-90$ of the $\alpha$-chain.

\section{Case History}

The subject of the present report was a 17-year-old nun, born in Dakwa, which is situated about $400 \mathrm{~km}$. north-north-east of

- Institute for Tropical Medicine, Prince Leopold, Antwerp.

t Medical Research Council Abnormal Haemoglobin Research Unit, University Department of Biochemistry, Cambridge.

‡ Present address: Agricultural Research Council Institute of Animal Physiology, Babraham, Cambs.
Kisangani (formerly Stanleyville). There are two tribes in this region, the Azande and the Amadi ; they are both Nilctes and not Bantu. While in Belgium as a temporary refugee from the rebellion in her part of the Congo Republic she was admitted to hospital for treatment of schistosomiasis, and the abnormal haemoglobin was discovered in the course of her routine examination. A family study was not possible.

\section{Examination of the Haemoglobin}

As in the previous subjects with Hbs $A$ and Stanleyville II there was no anaemia which could be linked with this haemoglobin variant. The variant was discovered and studied originally by starch-block electrophoresis, a discontinuous buffer system (Van Ros, 1966) being used. Otherwise the techniques were the same as those in the two previous investigations (Dherte et al., 1959 ; Hall-Craggs et al., 1964). The methods used for the isolation of the haemoglobin and the identification of the amino-acid substitution have been summarized recently, and the necessary references have been given by Sick, Beale, Irvine, Lehmann, Goodall, and MacDougall (1967) and Beale (1967).

It was possible to demonstrate that the haemoglobin moved like Hbs $S$ and $D$ on paper and starch-gel electrophoresis at pH 8.9 and 8.6 respectively, but that on chromatography on Amberlite resin IRC 50 at $\mathrm{pH} 6$ it moved more slowly. It did not separate from $A$ on agar-gel electrophoresis at $\mathrm{pH} 6$. It was shown to be an $\alpha$-chain variant because on starch-gel electrophoresis a second $\mathrm{Hb} \mathrm{A}_{2}$ was noted to be moving behind the normal $\mathrm{Hb} \mathrm{A}_{2}$ as would be expected when the variant haemoglobin differs from $\mathrm{Hb} A\left(\alpha_{2} A^{A} \beta_{2} A\right)$ in its $\alpha$-chains (Special Plate, Fig. 1). The variant $\alpha$-chains would give rise both to a variant $\mathrm{Hb} A\left(\alpha_{2} \times \beta_{2}^{A}\right)$ and to a variant $\mathrm{Hb} \mathrm{A}\left(\alpha_{2} \mathbf{X} \delta_{2}\right)$.

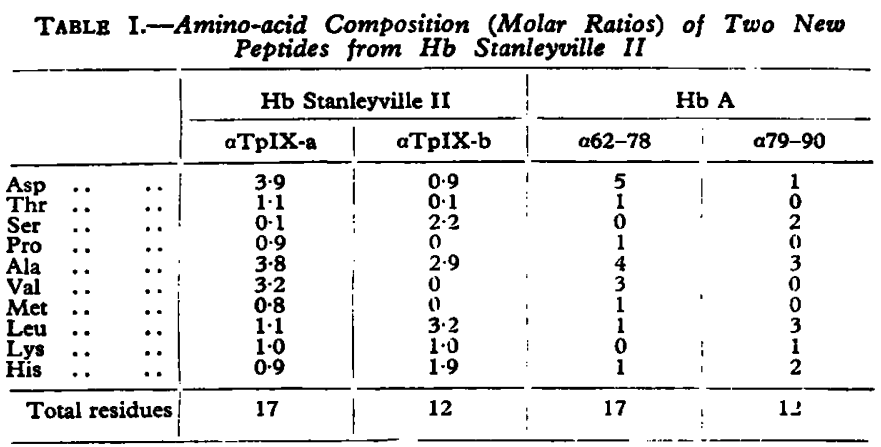


P. S. GARDNER $E T$ AL.: RAPID DIAGNOSIS OF HERPESVIRUS HOMINIS INFECTIONS IN SUPERFICIAL LESIONS

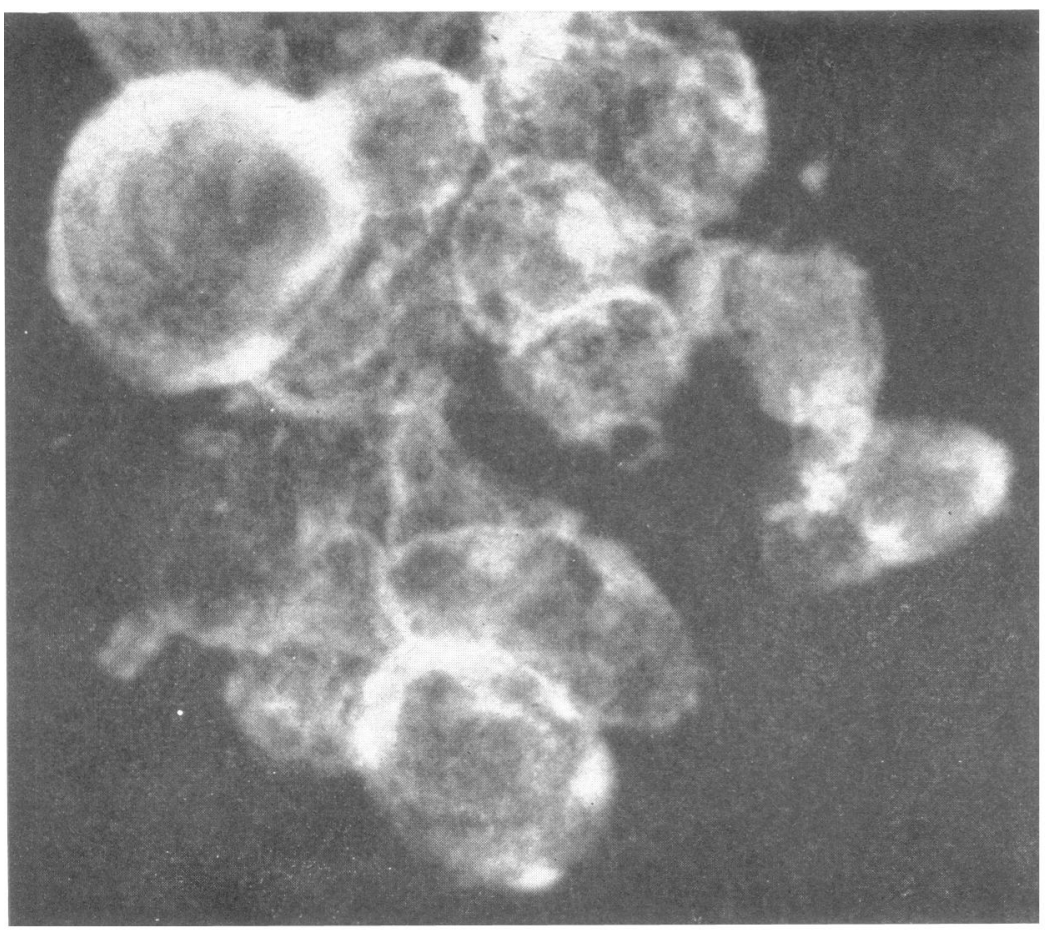

FIG. 1

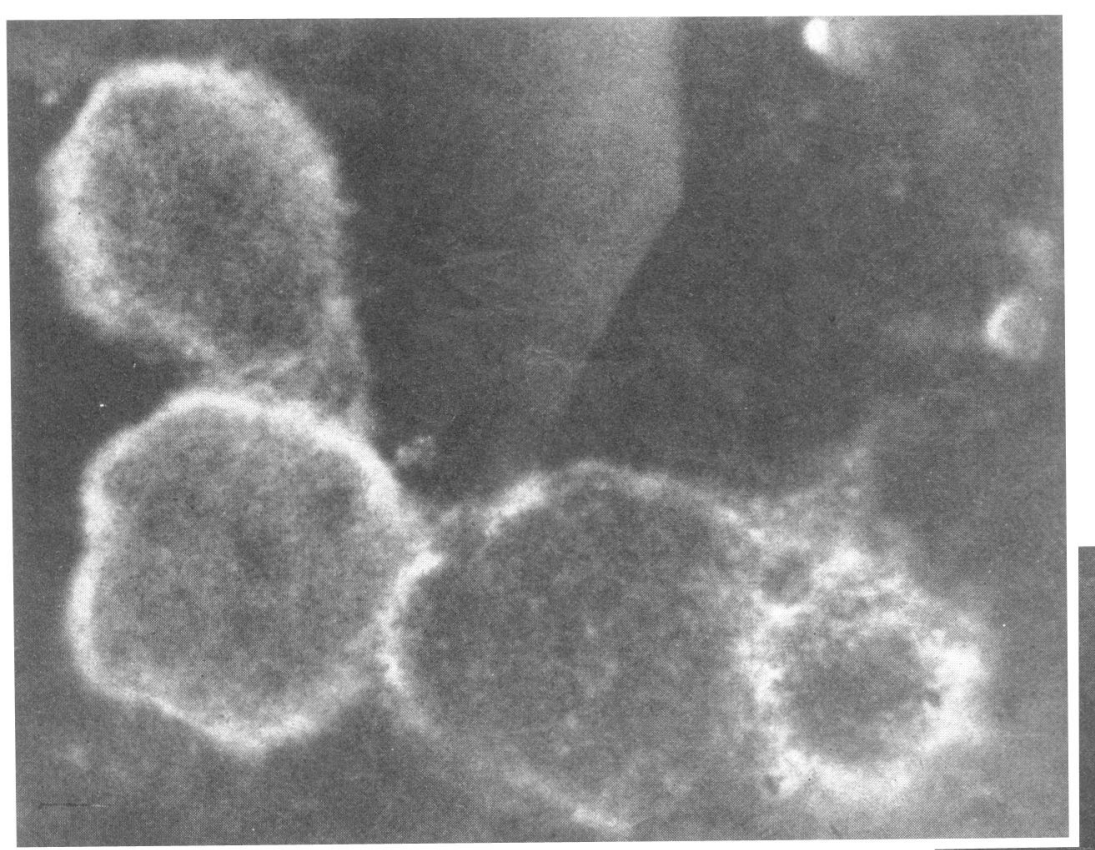

FIG 4

FIgS 4 and 5-Skın scrapings from patients with suspected Herpesvirus hominis infections, showing posituve fluorescence ( $\times 385$.

All preparations were treated with rabbit antiherpetic serum and Fluoroscan Plus; the appropriate controls were negative.

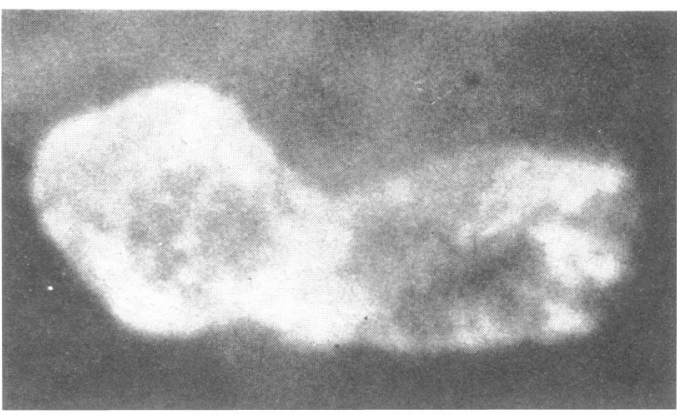

FIG. 2

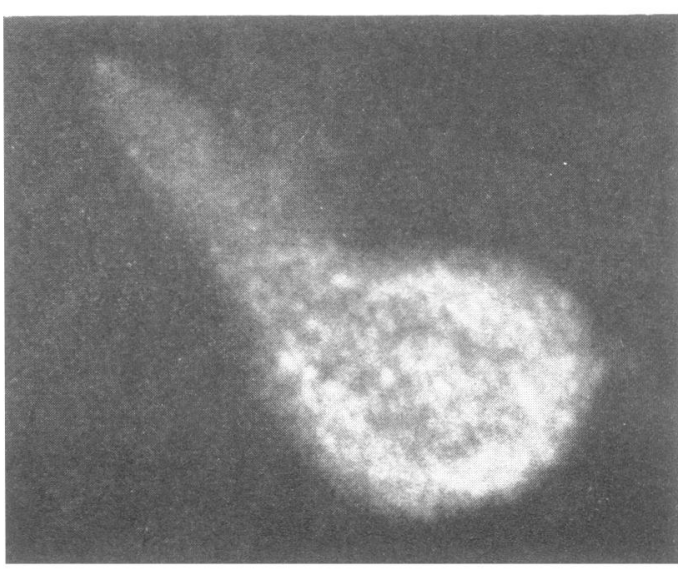

FIG. 3

Fig 1.-HEp2 cell culture infected with Herpesvirus homints, showing positive fluorescence. $(\times 425$.

FIGS. 2 and 3.-Isolated corneal epithelial cells from " dendritic ulcers," showing positive fluorescence. $(\times 500$. 